\title{
MINIREVIEW
}

\section{Type 2 Gaucher Disease: An Expanding Phenotype}

\author{
Nahid Tayebi, Deborah L. Stone, and Ellen Sidransky ${ }^{1}$ \\ Clinical Neuroscience Branch, NIMH, National Institutes of Health, Bethesda, Maryland 20892-4405
}

Received J uly 14, 1999, and in revised form August 11, 1999

\begin{abstract}
Key Words: glucocerebrosidase deficiency; hydrops fetalis; congenital ichthyosis; genotype; lethal.
\end{abstract}

Gaucher disease, the inherited deficiency of lysosomal glucocerebrosidase (EC 3.2.1.45), presents with diverse clinical phenotypes. The disorder is divided into three general types based on the presence and rate of progression of neurologic manifestations (1). Type 1 or nonneuronopathic Gaucher disease is by far the most common type and often presents with cytopenia, hepatosplenomegaly, or skeletal involvement. The age at onset of symptoms is variable, and many individuals with type 1 Gaucher disease are asymptomatic. Type 2 or acute neuronopathic Gaucher disease is universally progressive and fatal, with death by early childhood $(2,3)$. Patients with type 3 or chronic neuronopathic Gaucher disease have a variable degree of systemic involvement, as well as one or more neurologic manifestations. Often the sole neurologic symptom is the slowing and looping of the horizontal saccadic eye movements (4). In recent years, several atypical presentations of Gaucher disease have been recognized, including hydrops fetalis (3), congenital ichthyosis $(3,5,6)$, cardiovascular fibrosis and/or calcifications $(7,8)$, pulmonary hypertension (9), hydrocephalus (8), and Parkinsonian symptoms (10). The focus of

\footnotetext{
${ }^{1}$ To whom correspondence should be addressed at Clinical Neuroscience Branch, NIMH, BIdg. 49, Room B1EE 16, 49 Convent Drive, MSC4405, Bethesda, MD 20892-4405. Fax: (301) 4026438. E-mail: sidranse@irp.nimh.nih.gov.
}

this review is the expanding phenotype associated with type 2 Gaucher disease.

\section{TYPE 2 GAUCHER DISEASE}

Type 2 Gaucher disease is the rarest and most severe form of the disease and was first recognized as a distinct phenotype in 1927 (11). The enzymatic defect in glucocerebrosidase resulting in Gaucher disease was demonstrated in 1965, permitting the biochemical diagnosis of all three types of the disorder (12). Glucocerebrosidase activity can be measured in leukocytes, cultured fibroblasts, lymphoblasts, amniocytes, and chorionic villi samples $(13,14)$. However, neither the amount of residual enzyme activity nor the amount of stored lipid reliably differentiates type 2 from the other types of Gaucher disease $(1,15)$.

Classically, type 2 Gaucher disease was considered a disease of late infancy. A comprehensive review of 67 patients with type 2 Gaucher disease (2) described infants who appeared normal at birth but later developed hepatosplenomegaly, regression of developmental milestones, and arrest of growth. The age at death ranged from 1 month to 2 years, with an average of 9 months. All of the patients had signs of progressive neurologic disease, including cranial nerve and extrapyramidal tract involvement, and most had symptoms by the age of 6 months. The neurologic deterioration in these children progressed very rapidly, with death resulting from apnea or aspiration. Other common findings were hepatosplenomegaly, strabismus, and muscular hypertonicity or spasticity with persistent retroflex- 
ion of the neck. Estimates of the frequency of classic type 2 Gaucher disease in the general population have ranged from 1 in 100,000 to 1 in 500,000 births $(1,16)$.

\section{THE MOUSE MODEL}

In 1992 a mouse model of Gaucher disease was generated by targeted disruption of the murine glucocerebrosidase gene with a null allele (17). In this initial model, the targeting construct was designed to replace a portion of exons 9 and 10, which encodes approximately 30 amino acid residues, with a neomycin resistance gene. The resulting homozygous "knockout" mice had no glucocerebrosidase activity and had a particularly severe phenotype. Like humans with Gaucher disease, they accumulated glucocerebroside within Iysosomes of the reticuloendothelial cells, as demonstrated by thin-layer chromatography and electron microscopy. However, newborn mice had dramatic findings including cyanosis, irregular respirations, decreased feeding and movement, and dry cellophanelike, rugated skin. All of the knockout mice died within several hours of birth.

Several aspects of this mouse phenotype were initially perplexing. Gaucher disease had not been considered a neonatal disorder, and dermatologic manifestations were not commonly associated with Gaucher disease. However, this mouse model spurred a search for an analogous human population, and it soon became apparent from rare and scattered case reports that both congenital ichthyosis and neonatal lethality were also associated with glucocerebrosidase deficiency in humans $(3,6)$.

\section{THE COLLODION BABY PHENOTYPE}

The finding of congenital ichthyosis in neonates with severe Gaucher disease was first described in two siblings of Lebanese ancestry from Australia by Liu et al. in 1988 (5). These infants were born at term with collodion skin, hepatosplenomegaly, and apathy. Subsequently, many other cases have been reported, including two other unrelated Australian infants $(18,19)$, a black American infant $(20)$, a Turkish infant (21), a Dutch infant (22), two Afghani fetuses (23), an American fetus (24), and two Mexican siblings (25), all of whom had congenital ichthyosis as a prominent feature at presentation ( $\mathrm{Fig}$. 1A). A review of the earlier perinatal Gaucher literature has revealed several other reports that men- tioned patients with ichthyosis at birth, although the finding was not always emphasized (6). Several of these infants had joint abnormalities and contractures that were attributed to a restrictive dermatopathy in utero.

The presence of congenital ichthyosis in some infants with type 2 Gaucher disease was initially thought to be coincidental or due to the disruption of a contiguous gene (18). However, the similarities of the dermatologic findings, both clinically and histologically, in the patients with type 2 Gaucher disease and the Gaucher mice were striking, suggesting that the enzyme deficiency with the resultant abnormal glucocerebroside catabolism was responsible for the skin alterations seen in these infants (26). Skin abnormalities are observed both in preterm infants and in term babies with Gaucher disease. Particularly informative were case reports describing two siblings who appeared normal at birth except for congenital ichthyosis (25). Although the skin lesions resolved within weeks, several months later both infants developed rapidly progressive neurologic deterioration characteristic of acute neuronopathic Gaucher disease and died before 1 year of age. As a direct consequence of the recognition that Gaucher patients can present perinatally with congenital ichthyosis, an increased number of such cases have been newly diagnosed (22).

\section{THE DIAGNOSTIC VALUE OF EPIDERMAL ANALYSES}

Skin samples from the null allele Gaucher mouse were studied extensively. Histologic examination revealed hyperkeratosis and epidermal hyperplasia $(6,26)$. Ultrastructural studies demonstrated that the null allel e mice had abnormal, incompletely processed, lamellar body-derived sheets throughout the stratum corneum interstices. Additionally, the null allele mice had greatly increased transepidermal water loss as compared to their normal and heterozygote littermates (26).

The sphingolipid content and ratios in the stratum corneum are known to be essential for the maintenance of the epidermal permeability barrier $(27,28)$. Normally, glucocerebroside is abundant in mammalian epidermis, and ceramides are a major component of the intercellular bilayers $(28,29)$. The deficiency of glucocerebrosidase in the skin of the null allele mice resulted in both the observed histologic abnormality and the increased transepidermal water loss. Biochemical analyses confirmed that 


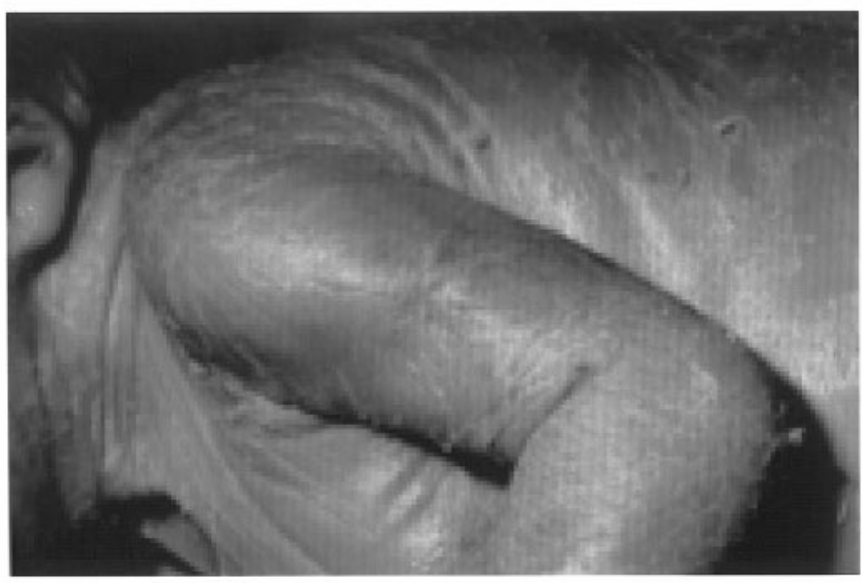

A

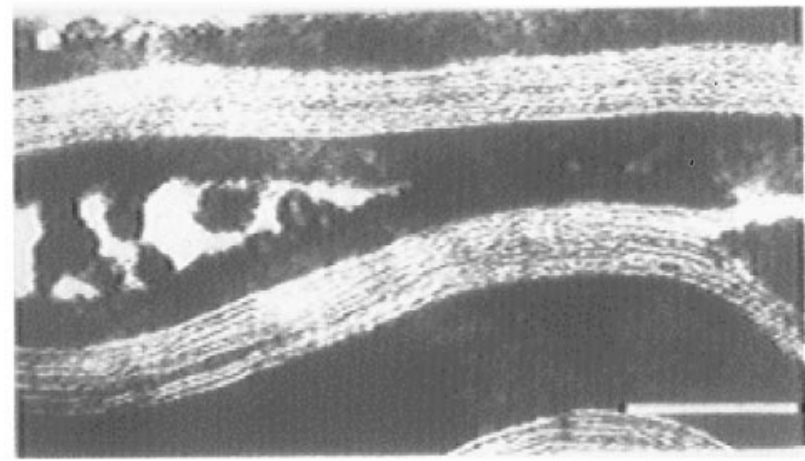

$\mathrm{C}$
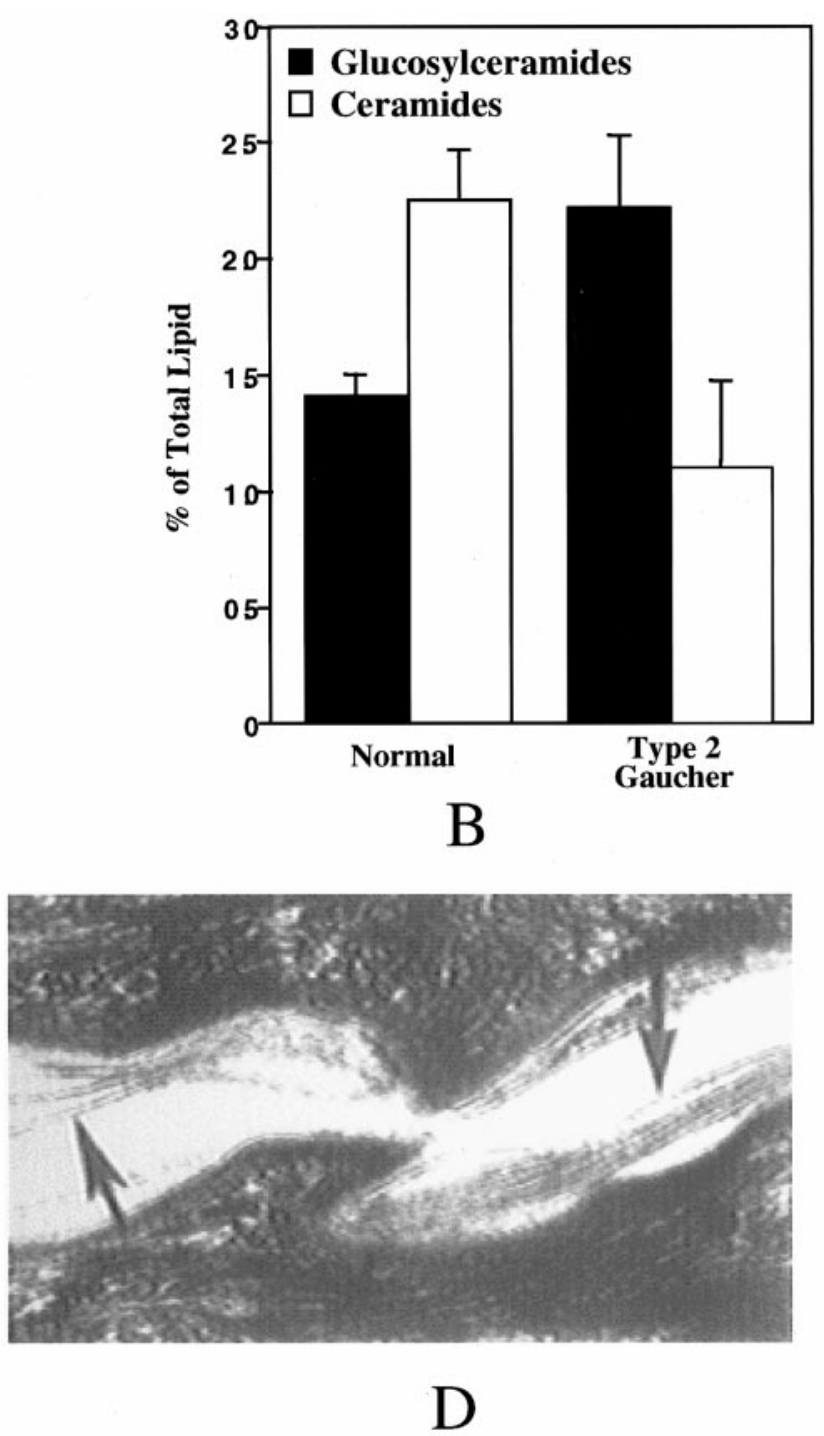

FIG. 1. Skin findings in type 2 Gaucher disease. (A) Dry, peeling skin seen in an infant with Gaucher disease and the collodion baby phenotype. (B) Graph showing the altered ratio of glucosylceramide to ceramide in epidermis from patients with type 2 Gaucher disease (see Ref. 30). (C) Ultrastructural study of epidermis from a patient with type 1 Gaucher disease demonstrating a normal lamellar bilayer structure. (D) Epidermis from a patient with type 2 Gaucher disease demonstrating disrupted lamellar bilayers (arrows).

skin samples from the type 2 Gaucher mice had 5- to 10-fold elevations in glucosylceramide and decreased levels of ceramides, substantiating the essential role of glucocerebrosidase in the generation of competent epidermal barriers (26). In the type 2 Gaucher mice the skin abnormalities led to increased epidermal water loss and dehydration, which may have contributed to their rapid demise.

The mouse studies encouraged a closer analysis of skin from patients with Gaucher disease. Epidermal analyses, including light and electron microscopic studies and measurement of lipid content, were con- ducted on patients with all three types of Gaucher disease using skin samples obtained by biopsy or at autopsy (30). The histologic appearance of skin from all studied patients with type 1 and type 3 Gaucher disease was identical to that of controls. In contrast, skin samples from patients with type 2 Gaucher disease had dense hyperkeratosis, epidermal hyperplasia, and inflammation. Ultrastructural analyses of all samples studied from patients with type 2 Gaucher disease $(n=8)$ showed abnormal arrays of loosely packed lamellar body-derived sheets replacing the normal lamellar bilayer unit structures in 
the stratum corneum (22,30-32) (Fig. 1D). The ultrastructural abnormalities were observed both in skin from ichthyotic neonatal patients and in the older infants with "classic" type 2 disease who had no clinical evidence of skin abnormalities (30). In contrast, electron microscopy performed on samples from patients with type 1 and type 3 disease displayed normal stratum corneum (Fig. 1C). The findings in patients with type 2 disease were virtually identical to those observed in skin samples from the null allele Gaucher mouse $(26,30)$.

Lipid analyses of normal human epidermis confirmed the predominance of ceramides over glucosylceramides. However, in samples of stratum corneum from infants with type 2 Gaucher disease, the ratio of glucosylceramide to ceramide was reversed, with the glucosylceramide content being 2-3 times higher than the ceramide content (Fig. 1B), as was seen in the mice with type 2 Gaucher disease (26). No abnormalities in the ratio of glucosylceramide to ceramide were observed in epidermis from patients with type 1 or type 3 disease (30).

These unique alterations in skin ultrastructure and lipid composition in patients with type 2 Gaucher disease appear to represent a consistent, early finding that permits the discrimination of type 2 from other types of Gaucher disease. The skin ultrastructural abnormalities in type 2 Gaucher disease are present regardless of whether clinical evidence of skin alterations exists (30). The observation that only patients with type 2 Gaucher disease have distinct ultrastructural and lipid biochemical abnormalities may permit rapid diagnostic testing and can be used to enable earlier counseling and intervention for the patients in whom Gaucher disease is diagnosed prenatally or in infancy. This distinction has important therapeutic implications, since patients with type 2 Gaucher disease are less likely to benefit significantly from treatment with enzyme replacement (33-35).

\section{PERINATAL LETHAL GAUCHER DISEASE}

The rapidly progressive murine phenotype prompted a new appreciation of a subset of patients with type 2 Gaucher disease: those who have a perinatal onset of symptoms. Manifestations in these cases are recognized prenatally, at birth, or shortly after birth. In 1992, a review of the type 2 Gaucher disease literature included 18 reports of severely affected fetuses and/or neonates (6). Several dozen further cases have since been described $(19,22-24$,
30-32,36-38). In each of these cases, death ensued either in utero or within hours to days after birth. Many of the infants or fetuses had hydrops fetalis. Because this phenotype had not been recognized as a distinct presentation of Gaucher disease, many of these cases were identified serendipitously, often at autopsy, and frequently after other siblings had died undiagnosed. The described infants had diverse ethnic and racial backgrounds. In several of the families there was a history of consanguinity. Postmortem pathologic studies performed on these infants demonstrated enlarged macrophages with glycolipid storage (Gaucher cells) in the spleen, liver, lungs, thymus, lymph nodes, adrenals, bone marrow, and CNS, similar to those seen in patients with classic type 2 Gaucher disease. A careful neuropathologic analysis of one fetus, which was miscarried at 33 weeks' gestation, revealed numerous periodic-acidSchiff (PAS)-positive macrophages. These were found isolated and in groups throughout the CNS, but most prominently in the basal ganglia, pons, medulla oblongata, and motor neurons of the spinal cord. The cerebellum and spinal cord showed extensive loss of Purkinje cells and lower motor neurons (37). Another affected fetus was found to have histologic changes at 20 weeks of gestation (32). Thus extensive pathologic alterations occur in human fetal tissues and begin early in gestation.

Although the association of Gaucher disease and hydrops fetalis has been established, the pathophysiol ogy of the phenomenon remains obscure. A recent survey of cases in the Netherlands revealed that there were a total of 10 cases of type 2 Gaucher disease diagnosed in Holland in the past 27 years. Five of the cases were found to have the perinatal lethal form (22). Likewise, a review of patients diagnosed with type 2 Gaucher disease in J apan included four infants with hydrops fetalis who succumbed at birth (38). Thus this phenotype may be more common than previously appreciated. Hydrops fetalis has been associated with other lysosomal storage diseases, including mucopolysaccharidosis types VII (39) and IV A (Morquio disease) (40), infantile free sialic acid storage disease (41), galactosialidosis (42), $G_{M 1}$ gangliosidosis (43), sialidosis (44), Niemann-Pick type $C$ disease (45), Farber disease (46), and I cell disease (47).

The reason for the early demise of these human fetuses and the type 2 Gaucher mouse is not fully understood. Remarkably, the degree of storage seen histologically in the brain is significantly less than that in other neuroviseral storage disorders, and the 
observed lesions are quite small and focal (48). This suggests that the CNS involvement may result from a neurotoxic effect rather than from lipid accumulation. Another lipid, glucosylsphingosine, is also hydrolyzed by glucocerebrosidase and is found in elevated levels in brain and other tissues from patients with type 2 Gaucher disease (49). Glucosylsphingosine is elevated in brains and livers from mice with type 2 Gaucher disease as early as Day 13 of gestation, progressively increasing throughout gestation $(50,51)$. In human fetuses with Gaucher disease we have found elevated glucosylsphingosine levels as early as 11 and 20 weeks of gestation (51). Another sphingosine derivative, galactosylsphingosine, appears to be responsible for the nervous system damage in a different lysosomal storage disorder, Krabbe disease $(52,53)$. The accumulation of this potentially neurotoxic compound during embryonal development may result in irreversible damage to developing nervous tissue, and could lead to the early demise of mice and human patients with type 2 Gaucher disease.

\section{MOLECULAR ANALYSES OF PATIENTS WITH TYPE 2 GAUCHER DISEASE}

The gene for human glucocer ebrosidase is located on chromosome 1q21, and over 100 mutations have been described to date $(54,55)$. There have been several publications describing the genotypes observed in patients with type 2 Gaucher disease. The first mutation described in an infant with type 2 Gaucher disease, L444P (56), continues to be the mutation most often encountered in this patient group. This mutation is present in the sequence of the glucocerebrosidase pseudogene, which is located $16 \mathrm{~kb}$ downstream of the human glucocerebrosidase gene $(57,58)$. Several different recombinant alleles, including fusion genes that include the L444P mutation, have been identified in patients with type 2 Gaucher disease $(31,37,59,60)$. Unfortunately the literature regarding the genotypic analysis of such patients is confusing, because many laboratories have used PCR-based genotyping techniques that may not identify a recombinant allele $(31,61,62)$.

We have performed genotypic analyses on DNA from 30 patients with type 2 Gaucher disease whose life spans ranged from intrauterine death at 22 weeks of gestation to survival until age 30 months (63). Seven of the patients presented with hydrops fetalis and died in utero or at birth. Seven infants had congenital ichthyosis. A common mutation iden- tified by screening was L 444P, found in 25 patient alleles. Sequencing demonstrated that L444P occurred alone in 10 alleles and as part of a recombinant allele in 15 alleles. Southern analyses and long-template PCR revealed different sites of recombination within the group with recombinant alleles $(31,32)$. Direct sequencing identified the remaining mutations, many of which were novel or rare (Table 1). Previously undescribed mutations were confirmed by restriction enzyme digests whenever the mutation created or obliterated a restriction site. To date we are aware of 44 different mutant alleles encountered in patients with type 2 Gaucher disease (Fig. 2), including several identified in other patient series (31,63-75). These studies demonstrate that there is considerable genotypic heterogeneity seen in patients with type 2 Gaucher disease, even among the infants with the most severe phenotypes.

Recombinant alleles that include the L444P mutation are frequently encountered in patients with type 2 Gaucher disease, although the site of recombination varies. Among the 13 patients in our series with type 2 Gaucher disease and recombinant L444P alleles, there are seven different sites of recombinations $(A-G)$, five of which occur in the region between intron 8 and intron $10(31,32,63)$ (Fig. 3). These recombinations often result in severe phenotypes, suggesting that this region may have an essential role in glucocerebrosidase function. However, point mutations, frameshift mutations, and splice-site mutations have also been found in patients with type 2 Gaucher disease and have been identified throughout the glucocerebrosidase gene (Fig. 2).

Clearly, screening PCR-amplified DNA for the presence or absence of specific point mutations is not adequate in this population, as many recombinant alleles and unique or rare mutations would not be correctly identified by routine mutation detection techniques. Homozygosity for a recombinant allele appears to result in early lethality, but recombinant alleles have been encountered in heterozygosity both in patients with prenatal manifestations and in classic type 2 patients. The large number of novel or rare mutations encountered in patients with type 2 Gaucher disease also complicates studies of genotype/phenotype correlation.

Recently the region on chromosome 1q21 surrounding the human glucocerebrosidase gene has been analyzed, and genes that are contiguous to the human glucocer ebrosidase gene have been identified 
TABLE 1

Type 2 Gaucher Disease

Patients presenting prenatally

Ethnic background Clinical

Genotype

Skin abnormalities
1. Ashkenazi
2. Afghani
3. Turkish
4. Cape Verdean
5. North American
6. North American
7. Lebanese

Hydrops

Hydrops

Hydrops

Hydrops

Hydrops

Hydrops

Ichthyosis, Hydrops

rec $A / I V S 10+2 \mathrm{~T}>\mathrm{G}$
rec $\mathrm{D} / \mathrm{rec} \mathrm{D}$
c.533delC/c.533delC
$\mathrm{H} 311 \mathrm{R} / \mathrm{H} 311 \mathrm{R}$
rec $\mathrm{B} / \mathrm{rec} \mathrm{B}$
$\mathrm{rec} \mathrm{D} / \mathrm{rec} \mathrm{D}$
$\mathrm{rec} \mathrm{D} / \mathrm{rec} \mathrm{D}$

Yes

Yes

$N A^{b}$

NA

NA

NA

Yes

Patients presenting at birth

Ethnic background

Clinical

Genotype

Skin abnormalities
8. Dutch/Surinamese
9. Australian
10. Greek
11. Lebanese
12. Lebanese
13. North American

Ichthyosis
Ichthyosis
Hepatosplenomegaly
Ichthyosis
Respiratory difficulty
Opisthotonus

R359X/N398F
C.1263-1317del/R257Q
rec C/H255Q
R120W/S196P
S196P/S196P
F259L/N 188K

Yes

Yes

NA

Yes

NA

NA

Patients presenting after several months

Ethnic background

14. Black American

15. North American

16. North American

17. North American

18. North American

19. Mexican

20. North American

21. Mexican

22. Swedish

23. Belgian

24. North American

25. North American

26. North American

27. North American

28. North American

29. Kenyan/Filipino

30. North American
Age at diagnosis

8 months
8 months
7 months
5 months
NA
5 months
NA
NA
3 months
6 months
6 months
12 months
9 months
4 months
5 months
4 months
NA

Genotype

rec E/E 41K

L444P/G202R

L444P/R163X

L444P/rec F

$\mathrm{L} 444 \mathrm{P} / \mathrm{rec} \mathrm{F}$

R131L/R131L

L444P/P415R

L444P/rec G

L444P/c.330delA

G202R/G202R

L444P + rec G/R257Q

L444P/Y 304C

A190E/G325R

$L 444 P / I V S 2+1 G>A$

G202R/G202R

$\mathrm{L} 444 \mathrm{P} / \mathrm{IVS} 2+1 \mathrm{G}>\mathrm{A}$

G325R/C342G
Skin abnormalities

Yes
Yes
NA
NA
NA
Yes
NA
NA
NA
NA
Yes
NA
NA
NA
NA
Yes
NA

a The term rec A-G refers to a recombinant allele with the site of crossover shown in Fig. 3.

${ }^{b} \mathrm{NA}$, information is not available.

in both its upstream and its downstream flanking regions $(58,76)$ (Fig. 4). Three genes have been mapped to the $32-\mathrm{kb}$ region upstream of the glucocerebrosidase gene (76). The most distal of these three is a protein kinase (clk-2) (77). A second gene, propin2, is located $15 \mathrm{~kb}$ upstream of the glucocerebrosidase gene and encodes a 1.5-kb cDNA with strong homology to a rat secretory carrier membrane protein (SCAMP) (78). The function of cotel, a gene located only $6 \mathrm{~kb}$ upstream of the glucocerebrosidase gene, is still unknown. Another gene, metaxin, was discovered downstream of the glucocerebrosidase gene, between the glucocerebrosidase pseudogene and the gene for human thrombospondin 3 (58). The metaxin gene is transcribed convergently to the human glucocerebrosidase gene and shares a common bidirectional promoter with the thrombospondin 3 gene. A pseudogene for hu- 


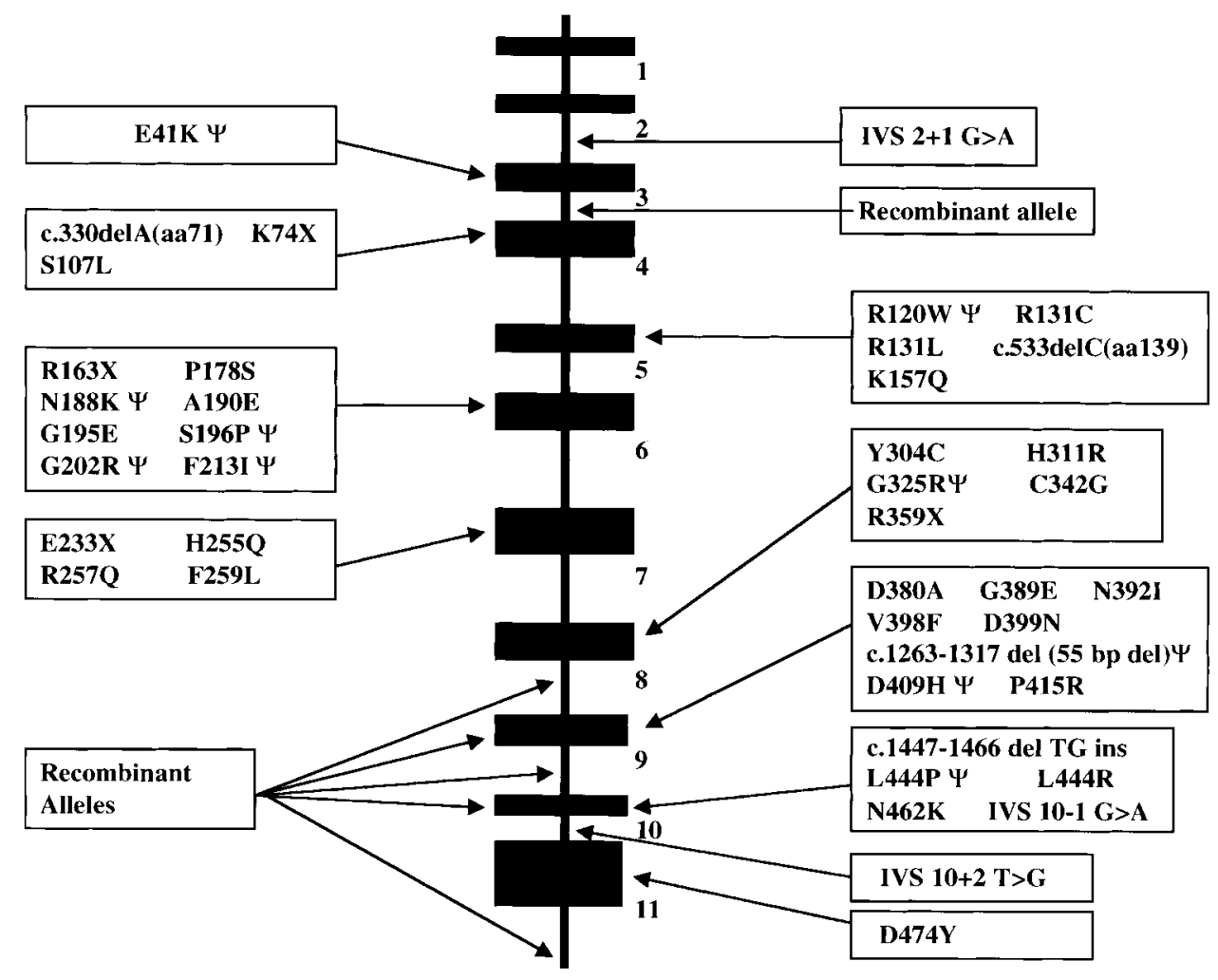

FIG. 2. The location of the mutations identified in patients with type 2 Gaucher disease. The symbol $\Psi$ denotes a mutation which is present in the pseudogene sequence.

man metaxin is located immediately downstream of glucocer ebrosidase (58) (Fig. 4). Thus six genes and two pseudogenes are found within $75 \mathrm{~kb}$ of sequence. It is intriguing to speculate that one or more of these contiguous genes could potentially be interrupted or mutated as recombinant glucocerebrosidase alleles arise $(76,79)$.

\section{THERAPY FOR TYPE 2 GAUCHER DISEASE}

Unfortunately there is currently no treatment that can reverse or halt the disastrous neurologic sequelae associated with type 2 Gaucher disease. Enzyme replacement therapy with modified placental human glucocerebrosidase (alglucerase) and recombinant glucocerebrosidase (imiglucerase) is widely used in type 1 Gaucher disease and is effective in treating many of its visceral and hematologic manifestations. However, its use in patients with type 2 Gaucher disease has been limited and disappointing (33-35). Even presymptomatic therapy, given from birth to an infant identified prenatally, failed to alter the inevitable neurol ogic outcome (34). The therapy partially treats the anemia and organomegaly in patients with type 2 Gaucher disease and can prolong life slightly but is currently not recommended, as affected children continue to deteriorate neurologically. Attempts have been made to deliver the enzyme directly into the CNS by intraventricular infusions through an Omaya reservoir, but in all three patients who received this treatment, neurologic deterioration continued (35). Since pathologic and biochemical studies have indicated that CNS involvement in type 2 Gaucher disease begins early in gestation, strategies aimed at treating the disease after birth may already be too late.

Another therapeutic approach being considered for Gaucher disease involves the use of inhibitors of glycolipid biosynthesis. These compounds may transverse the blood-brain barrier and potentially be used in patients with neuronopathic Gaucher disease. In vitro studies with an $\mathrm{N}$-alkyl derivative of the imino sugar, $\mathrm{N}$-butyldeoxynojirimycin (NBDNJ ), demonstrated that this compound prevented the storage of glucocerebroside in cells (80). This 

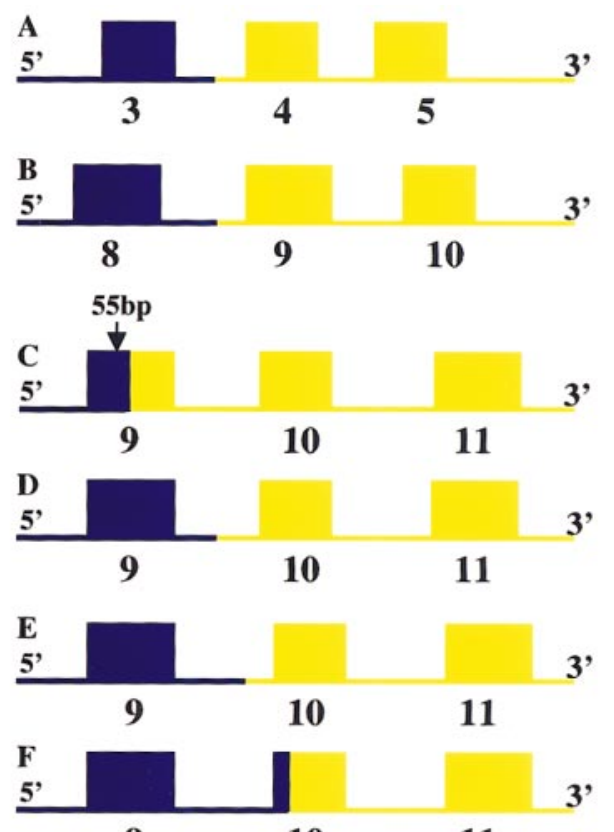

$9 \quad 10 \quad 11$

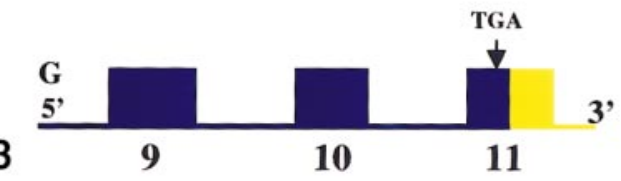

Clk2 Propin1 Cote1 Glucocerebrosidase Glucocerebrosidase Thrombospondin3 Muc1 pseudogene

4

\section{Metaxin}

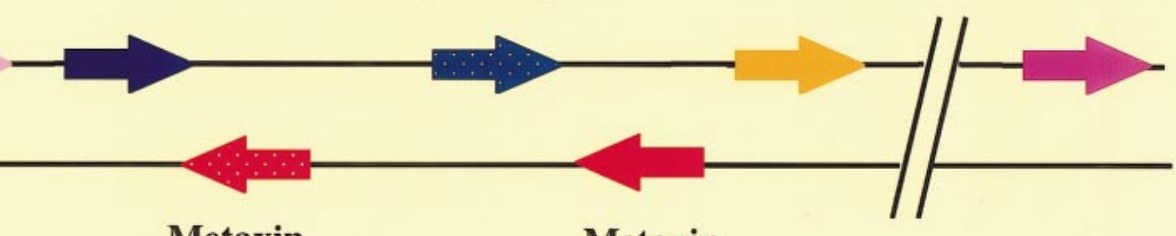

pseudogene

FIG. 3. Schematic representation of the site of seven recombinant alleles resulting from crossover between the glucocerebrosidase gene and pseudogene identified in patients with type 2 Gaucher disease. The approximate sites of crossover are: (A) The crossover occurred in intron 3 (RecA). (B) The crossover occurred at the end of intron 8 (RecB). (C) The crossover occurred in exon 9, between the 55-bp deletion and the D409H mutation (RecC). (D) The crossover occurred early in intron 9 (RecD). (E) The crossover occurred later in intron 9 (RecE). (F) The crossover occurred at the beginning of exon 10 (RecF). (G) The crossover occurred at or after exon 11 (RecG).

FIG. 4. The relative location of 7 genes and 2 pseudogenes on chromosome 1q21 (see Ref. 76).

compound alone or in conjunction with enzyme replacement therapy may have potential as a therapy for Gaucher patients.

\section{CONCLUSIONS}

The lysosomal storage diseases are characterized by a wide spectrum of clinical phenotypes. The most se- vere forms of these diseases are increasingly diagnosed prenatally or in the newborn period. Gaucher disease is now known to be one of the inborn errors of metabolism that can result in perinatal mortality. Hydrops fetalis and collodion skin may be perinatal presentations of type 2 Gaucher disease, and new cases have been identified with greater frequency since these associations have been appreciated. 
Genotypic analyses of patients with type 2 Gaucher disease demonstrate significant genotypic heterogeneity even among clinically similar patients and the most severe cases. Recombinant alleles arising from recombination between the gene and its pseudogene are particularly prevalent, and DNA from patients with type 2 Gaucher disease should be specifically examined for these alleles, which result in early lethality in homozygous individuals. Nevertheless a large number of rare point mutations are encountered in patients with type 2 Gaucher disease, and routine DNA testing looking for common mutations is not an efficient means of screening or establishing the diagnosis, unless the mutations are known for a given family.

The mechanisms contributing to the devastating neurologic manifestations encountered in type 2 Gaucher disease remain to be elucidated. The possible toxicity of glucosylsphingosine and the involvement of other genes, especially those contiguous to glucocerebrosidase, merit further investigation. Unfortunately there are currently no therapeutic interventions available that reverse the CNS damage in these patients. Thus, although significant advances have been made in the clinical and molecular diagnoses of type 2 Gaucher disease, major challenges and areas of future research remain.

\section{REFERENCES}

1. Beutler E, Grabowski GA. Gaucher disease. In The Metabolic and Molecular Bases of Inherited Disease (Scriver CR, Beaudet AL, Sly WS, et al., Eds.). New York: McGraw-Hill, pp 2641-2670, 1995.

2. Frederickson DS, Sloan HR. Glucosylceramide lipidoses: Gaucher's disease. In The Metabolic Basis of I nherited Disease (Stanbury J B, Wyngaarden J B, Frederickson DS, E ds.). New York: McGraw-Hill, pp 730-759, 1972.

3. Sidransky E. New perspectives in type 2 Gaucher disease. Adv in Pediatr 44:73-107, 1997.

4. Cogan DG, Chu FC, Reingold D, Barranger J . Ocular motor signs in some metabolic diseases. Arch Ophthalmol 99:1802-1808, 1981.

5. Liu K, Commens C, Chong R, J aworski R. Collodion babies with Gauchers disease. Arch Dis Child 63:854- 856, 1988.

6. Sidransky E, Sherer DM, Ginns El. Gaucher disease in the neonate: A distinct Gaucher phenotype is analogous to a mouse model created by targeted disruption of the glucocerebrosidase gene. Pediatr Res 32:494-498, 1992.

7. Abrahamov A, Elstein D, Gross-Tsur V, Farber B, Glaser $Y$, Hadas-Halpern I, Ronen S, Tafakjdi M, Horowitz M, Zimran A. Gaucher's disease variant characterized by progressive calcification of heart valves and unique genotype. Lancet 346:1000-1003, 1995.

8. Uyama E, Takahashi K, Owada M, Okamura R, Naito M,
Tsuji S, Kawasaki S, Araki S. Hydrocephalus, corneal opacities, deafness, valvular heart disease, deformed toes and leptomeningeal fibrous thickening in adult siblings: A new syndrome associated with glucocerebrosidase deficiency and a mosaic population of storage cells. Acta Neurol Scand 86:407- 420, 1992.

9. Elstein D, Klutstein MW, Lahad A, Abrahamov A, HadasHalpern I, Zimran A. Echocardiographic assessment of pulmonary hypertension in Gaucher's disease. Lancet 351:1544-1546, 1998.

10. Neudorder O, Giladi N, Elstein D, Abrahamov A, Turezkite $T$, Aghai $E$, Reches A, Bembi B, Zimran A. Occurrence of Parkinson's syndrome in type 1 Gaucher disease. Q J Med 89:691- 694, 1996.

11. Oberling C, Woringer P. La Maladie de Gaucher chez le nourrissor. Rev Fr Pediatr 3:475-532, 1927.

12. Brady RO, Kanfer J N, Shapiro D. Metabolism of glucocerebrosides. II. Evidence of enzymatic deficiency in Gaucher's disease. Biochem Biophys Res Commun 18:221-225, 1965.

13. Beutler E, Kuhl W. Detection of the defect of Gaucher's disease and its carrier state in peripheral-blood leukocytes. Lancet 1:612-613, 1970.

14. Evans MI, Moore C, Kolodny EH, Casassa M, Schulman J D, Landsberger EJ, Karson EM, Dorfman AD, Larsen J W J r, Barranger J A. Lysosomal enzymes in chorionic villi, cultured amniocytes, and cultured skin fibroblasts. Clin Chim Acta 157:109-113, 1986.

15. Sidransky E, Ginns EI. Phenotypic and genotypic heterogeneity in Gaucher disease: Implications for genetic counseling. J Genet Couns 3:13-22, 1994.

16. Grabowski GA. Gaucher disease. Enzymology, genetics and treatment. Adv Hum Genet 21:377- 441, 1993.

17. Tybulewicz VLJ, Tremblay ML, LaMarca ME, Willemsen R, Stubblefield BK, Winfield S, Zablocka B, Sidransky E, Martin BM, Huang SP, Mintzer KA, Westphal H, Mulligan RC, Ginns El. Animal model of Gaucher's disease from targeted disruption of the mouse glucocerebrosidase gene. Nature 357:407-410, 1992.

18. Lipson AH, Rogers M, Berry A. Collodion babies with Gaucher's disease: A further case. Arch Dis Child 66:667, 1991.

19. Rowlands $\mathrm{S}$, Murray $\mathrm{H}$. Prenatal ultrasound findings in a fetus diagnosed with Gaucher's disease (type 2) at birth. Prenat Diag 17:765-769, 1997.

20. Sherer DM, Metlay L, Sinkin RA, Mongeon C, Lee RE, Wood $S$ J r. Congenital ichthyosis with restrictive dermopathy and Gaucher's disease: A new syndrome with associated prenatal diagnostic and pathology findings. Obstet Gynecol 81: 843- 844, 1993.

21. Ince Z, Coban A, Peker O, Ince U, Can G. Gaucher disease associated with congenital ichthyosis in the neonate. Eur J Pediatr 154:418, 1995.

22. Stone DL, vanDiggelen OP, deKlerk JBC, Gaillard J LJ, Niermeijer MF, Willemsen R, Tayebi N, Sidransky E. Is the perinatal lethal form of Gaucher disease more common than classic type 2 Gaucher disease? Eur J Hum Genet 7:505509, 1999.

23. Sidransky E, Tayebi N, Stubblefield BK, Eliason W, Klineburgess A, Pizzolato G-P, Cox J N, Porta J, Bottani A, DeLozier-Blanchet CD. The clinical, molecular, and patho- 
logical characterization of a family with two cases of lethal perinatal type 2 Gaucher disease. J Med Genet 33:132-136, 1996.

24. Grace ME, Ashton-Prolla P, Pastores GM, Soni A, Desnick RJ. Non-pseudogene-derived complex acid $\beta$-glucosidase mutations causing mild type 1 and severe type 2 Gaucher disease. J Clin Invest 103:817- 823, 1999.

25. Fujimoto A, Tayebi N, Sidransky E. Congenital ichthyosis preceding neurol ogic symptoms in two sibs with type 2 Gaucher disease. Am J Med Genet 59:356-358, 1995.

26. Holleran WM, Ginns EI, Menon GK, Grundmann J U, Fartasch M, McKinney C, Elias PM, Sidransky E. Consequences of $\beta$-glucocerebrosidase deficiency in epidermis: UItrastructure and permeability barrier alterations in Gaucher disease. J Clin Invest 93:1756-1764, 1994.

27. Yardley HJ , Summerly R. Lipid metabolism in normal and diseased epidermis. Pharmacol Ther 13:347-383, 1981.

28. Holleran WM, Takagi Y, Menon GK, Legler G, Feingold KR, Elias PM. Processing of epidermal glucosylceramides is required for optimal mammalian cutaneous permeability barrier function. J Clin Invest 91:1656-1664, 1993.

29. Elias PM, Menon GK. Structural and lipid biochemical correlates of the epidermal permeability barrier. Adv Lipid Res 24:1-26, 1991.

30. Sidransky E, Fartasch M, Lee RE, Metlay LA, Abella S, Zimran A, Gao W, Elias PM, Ginns El, Holleran WM. Epidermal abnormalities may distinguish type 2 from type 1 and type 3 of Gaucher disease. Pediatr Res 39:134-141, 1996.

31. Tayebi N, Reissner K, Lau EK, Stubblefield BK, Sidransky E. Genotypic heterogeneity and phenotypic variation among patients with type 2 Gaucher disease. Pediatr Res 43:571578, 1998.

32. Reissner K, Tayebi N, Stubblefield BK, Blitzer M, MadelIena A, Carson E, Sidransky E. Heteroallelism for a novel recombinant allele and a rare splicejunction mutation in the glucocerebrosidase locus presenting with hydrops fetalis. Mol Genet Metab 63:281-288, 1998.

33. Erikson A, J ohansson K, Mansson J E. Enzyme replacement therapy of infantile Gaucher disease. Neuropediatrics 24: 237-238, 1993.

34. Bove KE, Daugherty C, Grabowski GA. Pathological finding in Gaucher disease type 2 patient following enzyme therapy. Hum Pathol 26:1040-1045, 1995.

35. Bembi B, Ciana G, Zanatta M, Bottega M, Pelos G, Gornati R, Berra B. Cerebrospinal-fluid infusion of alglucerase in the treatment of acute neuronopathic Gauchers disease. Pe diatr Res 38:A425, 1995.

36. Strasberg PM, Skomorowski MA, Warren IB, Hilson WL, Callahan JW, Clarke JTR. Homozygous presence of the crossover (fusion gene) mutation identified in a type II Gaucher disease fetus: Is this analogous to the Gaucher knockout mouse model? Biochem Med Metab Biol 53:16-21, 1994.

37. Tayebi N, Cushner S, Kleijer W, Lau E, Damschroder-Williams PJ , Stubblefield BK, Hollander J D, Sidransky E. Prenatal lethality of a homozygous null mutation in the human glucocerebrosidase gene. Am J Med Genet 73:41- 47, 1997.

38. Eto Y, Ida H. Clinical and molecular characteristics of J apanese Gaucher disease. Neurochem Res 24:207-211, 1999.
39. Vervoort R, Islam MR, Sly WS, Zabot MT, Kleijer WJ, Chabas A, Fensom A, Young EP, Liebaers I, Lissens W. Molecular analysis of patients with $\beta$-glucuronidase deficiency presenting as hydrops fetalis or as early mucopolysaccharidosis VII. Am J Hum Genet 58:457- 471, 1996.

40. Applegarth DA, Toone J R, Wilson RD, Yong SL, Baldwin VJ. Morquio disease presenting as hydrops fetalis and enzyme analysis of chorionic villus tissue in a subsequent pregnancy. Pediatr Pathol 7:593-599, 1987.

41. Pueschel SM, O'Shea PA, Alroy J, Ambler MW, Dangond F, Daniel PF, Kolodny E. Infantile sialic acid storage disease associated with renal disease. Pediatr Neurol 4:207-212, 1988.

42. Zammarchi E, Donati MA, Morrone A, Donzelli GP, Zhou $X Y$, d'Azzo A. Early-infantile galactosialidosis: Clinical, biochemical, and molecular observations in a new patient. Am J Med Genet 64:453- 458, 1996.

43. Tasso J, Martinez-Gutierrez A, Carrascosa C, Vazquez S, Tebar R. $\mathrm{G}_{\mathrm{MI}}$-gangliosidosis presenting as nonimmune hydrops fetalis: A case report. J Perinat Med 24:445-449, 1996.

44. Aylsworth AS, Thomas GH, Hood J L, Malouf N, Libert J . A severe infantile sialidosis: Clinical, biochemical and microscopic features. J Pediatr 96:662-668, 1980.

45. MaconochieIK, Chong S, Mieli-Vergani G, Lake BD, Mowat AP. Fetal ascites: An unusual presentation of Niemann-Pick disease type C. Arch Dis Child 64:1391-1393, 1989.

46. Kattner E, Schäfer A, Harzer K. Hydrops fetalis: Manifestation in lysosomal storage diseases including Farber disease. Eur J Pediatr 156:292-295, 1997.

47. Appelman Z, Blumberg BD, Golabi M, Golbus MS. Nonimmune hydrops fetalis may be associated with an elevated $\Delta \mathrm{OD}_{450}$ in the amniotic fluid. Obstet Gynecol 71:1005-1008, 1988.

48. Willemsen R, Tybulewicz V, Sidransky E, Eliason WK, Martin BM, LaMarca ME, Reuser AJ J , Tremblay M, Westphal H, Mulligan R, Ginns EI. A biochemical and ultrastructural evaluation of the type 2 Gaucher mouse. Mol Chem Neuropathol 24:170-192, 1995.

49. Nilsson $\mathrm{O}$, Svennerholm L. Characterization and quantitative determination of gangliosides and neutral glycosphingolipids in human liver. J Lipid Res 23:327-333, 1982.

50. McKinney CE, Sidransky E, LaMarca ME, Riviere I, Holleran WM, Martin BM, Willemsen R, Mulligan RC, Ginns EI. Gaucher disease: A tale of two species. Ment Retard Dev Disabil Res Rev 1:79- 86, 1995.

51. Orvisky E, Martin BM, Tayebi N, Karson E, Samimi R, Sciarretta K, Ginns El, Sidransky E. Glucosylsphingosine accumulation in patients with type 2 Gaucher occurs early in gestation. Am J Hum Genet 63:A271, 1998.

52. Tanaka K, Nagara H, Kobayashi T, Goto I. The Twitcher mouse: Accumulation of galactosylsphingosine and pathology of the central nervous system. Brain Res 482:347-350, 1989.

53. Suzuki K, Suzuki Y. Galactoceramide lipidosis: Globoid cell leukodystrophy. In The Metabolic Basis of I nherited Disease (Stanbury J B, Wyngarden J B, Fredrickson DS, et al., Eds.). New York: McGraw Hill, pp 857- 880, 1983. 
54. Beutler E, Gel bart T. Hematologically important mutations: Gaucher disease. Blood Cells Mol Dis 24:2- 8, 1998.

55. Grabowski GA, Horowitz M. Gaucher's disease: Molecular, genetic and enzymological aspects. In Gaucher's Disease: Baillière's Clinical Haematology, Vol. 10 (Zimran A, Ed.). London: Baillière Tindall, pp 635- 656, 1997.

56. Tsuji S, Choudary PV, Martin BM, Stubblefield BK, Mayor JA, Barranger J A, Ginns El. A mutation in the human glucocerebrosidase gene in neuronopathic Gaucher's disease. N Engl J Med 316:570-575, 1987.

57. Horowitz M, Wilder S, Horowitz Z, Reiner O, Gelbart T, Beutler $E$. The human glucocerebrosidase gene and pseudogene: Structure and evolution. Genomics 4:87-96, 1989.

58. Long GL, Winfield S, Adolph KW, Ginns EI, Bornstein P. Structure and organization of the human metaxin gene (MTX) and pseudogene. Genomics 33:177-184, 1996.

59. Latham T, Grabowski GA, Theophilus BDM, Smith FI. Complex alleles of the acid $\beta$-glucocerebrosidase gene in Gaucher disease. Am J Hum Genet 47:49- 86, 1990.

60. Horowitz M, Zimran A. Mutations causing Gaucher disease. Hum Mutat 3:1-11, 1994.

61. Tayebi N, Stern H, Dymarskaia I, Herman J, Sidransky E. 55-base pair deletion in certain patients with Gaucher disease complicates screening for common Gaucher alleles. Am J Med Genet 66:316-319, 1996.

62. Tayebi N, Cushner SR, Sidransky E. Differentiation of the glucocer ebrosidase gene from pseudogene by long-template PCR: Implications for Gaucher disease. Am J Hum Genet 59:740-741, 1996.

63. Stone D, Tayebi N, Stubblefield B, Madike V, Sidransky E. Glucocerebroside mutations encountered in patients with type 2 Gaucher disease. Submitted for publication.

64. I da H, Rennert OM, Kawame H, I to T, Maekawa K, Eto Y. Mutation screening of $17 \mathrm{~J}$ apanese patients with neuropathic Gaucher's disease. Hum Genet 98:167-171, 1996.

65. Grace ME, Desnick RJ, Pastores GM. Identification and expression of acid $\beta$-glucosidase mutations causing severe type 1 and neurologic type 2 Gaucher's disease in nonJ ewish patients. J Clin Invest 99:2530-2537, 1997.

66. Latham TE, Theophilus BDM, Grabowski BA, Smith PI. Heterogeneity of mutations in the acid-glucosidase gene of Gaucher's disease patients. DNA Cell Biol 10:15-21, 1991.

67. Eyal N, Wilder S, Horowitz M. Prevalent and rare mutations among Gaucher patients. Gene 96:277-283, 1990.
68. Beutler E, Gel bart T. Two new Gaucher's disease mutations. Hum Genet 93:209-210, 1994.

69. Zimran A, Elstein D, Abrahamov A, Kuhl W, Brown KH, Beutler E. Prenatal molecular diagnosis of Gaucher. Prenat Diagn 15:1185-1188, 1995.

70. Seri M, Filocamo M, Corsolini F, Bembi B, Barbera C, Gatti R. A rare $\mathrm{G}^{6490 \rightarrow}$ A substitution at the last nucleotide of exon 10 of the glucocerebrosidase gene in two unrelated Italian Gaucher patients. Clin Genet 48:123-127, 1995.

71. Uchiyama A, Tomatsu S, Kondo N, Suzuki Y, Shimozawa N, Fukuda S, Sukegawa K, Taki N, Inamori H, Orii T. New Gaucher's disease mutations in exon 10: A novel L444R mutation produces a new $\mathrm{Ncil}$ site the same as L444P. Hum Mol Genet 3:1183-1184, 1994.

72. Choy FYM, Wei C. I dentification of a new mutation (P178S) in an African-American patient with type 2 Gaucher's disease. Hum Mutat 5:345-347, 1995.

73. Hatton CE, Cooper A, Whitehouse C, Writh J E. Mutation analysis in 46 British and Irish patients with Gaucher's disease. Arch Dis Child 77:17-22, 1997.

74. Sinclair G, Choy FYM, Humphries L. A novel complex allele and two new point mutations in type 2 (acute neuronopathic) Gaucher disease. Blood Cells Mol ecules Dis 24:420427, 1998.

75. Deming A, Beutler E. Six new Gaucher disease mutations. Acta Haematol 99:80- 82, 1998.

76. Winfield SL, Tayebi N, Martin BM, Ginns El, Sidransky $\mathrm{E}$. Identification of three additional genes contiguous to the glucocerebrosidase locus on chromosome 1q21: I mplications for Gaucher's disease. Genome Res 7:1020-1026, 1997.

77. Hanes J J, von der Kammer H, Klaudiny JJ, Scheit KH. Characterization by CDNA cloning of two new human protein kinases: Evidence by sequence comparison for a new family of mammalian protein kinases. J Mol Biol 244:665672, 1994.

78. Brand SH, Castle J D. SCAMP 37, a new marker within the general cell surface recycling system. EMBO J 12:37533761, 1993.

79. Sidransky E, Ginns EI. Gaucher disease plus. J Med Genet 34:876- 879, 1997.

80. Platt FM, Neises GR, Karlsson GB, Dwek RA, Butters TP. $\mathrm{N}$-Butyldeoxygalactonojirimycin inhibits glycolipid biosynthesis but does not affect $\mathrm{N}$-linked oligosaccharide processing. J Biol Chem 43:27108-27114, 1994. 